\section{Winter Stem Cutting Propagation of 'Dwarf Burford' Holly without Use of a Conventional Auxin Treatment}

\author{
Eugene K. Blythe ${ }^{1,3,5}$ and Jeff L. Sibley ${ }^{2,4}$
}

AdDITIONAL InDEX wORDs. Ilex cornuta 'Burfordii Nana', Ilex cornuta 'Burfordii Compacta', vegetative propagation, root-promoting compounds

SumMaRY. 'Dwarf Burford' holly (Ilex cornuta 'Dwarf Burford') is a significant nursery crop and is widely used in landscapes in U.S. Department of Agriculture hardiness zones 7 to 9 . Stem cuttings can be rooted at multiple times during the year, provided cutting wood is sufficiently mature, with auxin treatments traditionally used to encourage rooting. This study was conducted to determine if auxin treatment could be eliminated, thus reducing labor and chemical requirements in the cutting propagation process. In three experiments, terminal stem cuttings of 'Dwarf Burford' holly were taken in winter, prepared with and without use of a basal quick-dip in an auxin solution, and rooted in a warm, high-humidity environment. Rooting percentages for nontreated cuttings and cuttings treated with $2500 \mathrm{ppm}$ indole-3-butyric acid (IBA) + 1250 ppm 1-naphthaleneacetic acid (NAA) were similar, while treatment of cuttings with $5000 \mathrm{ppm} \mathrm{IBA}+2500 \mathrm{ppm}$ NAA resulted in a decrease in rooting percentage. The number of primary roots and total root length were similar among the three treatments, except in one experiment where total root length was greater with auxin-treated cuttings than with nontreated cuttings. Initial shoot growth responses were variable among the three experiments. The treatment of cuttings with auxin was not required for successful rooting and can be eliminated from the process for winter stem cutting propagation of 'Dwarf Burford' holly.

$\mathrm{D}$ warf Burford' holly (synonyms: 'Burfordii Nana' and 'Burfordii Compacta') was first discovered in 1947 among vegetatively propagated hollies (Galle, 1997) and has historically been one of the major holly cultivars in ornamental nursery production (Berry, 1994). 'Dwarf Burford' holly is easy to grow, can be readily maintained in the landscape, and is suitable for use in small landscapes (Dirr, 1998). Recommended for landscapes in U.S.

This paper was approved for publication as Journal Article No. J-11314 of the Mississippi Agricultural and Forestry Experiment Station, Mississippi State University.

The mention of trade names or commercial products in this article is solely for the purpose of providing specific information and does not imply recommendation or endorsement to the exclusion of other products that may also be suitable.

We thank Warren Copes, David St. Louis, and Jian-Zhong Sun for reviewing an early draft of this manuscript.

${ }^{1}$ Coastal Research and Extension Center and Department of Plant and Soil Sciences, Mississippi State University, South Mississippi Branch Experiment Station, P.O. Box 193, Poplarville, MS 39470

${ }^{2}$ Department of Horticulture, Auburn University, Auburn, AL 36849

${ }^{3}$ Assistant Research Professor.

${ }^{4}$ Alumni Professor.

${ }^{5}$ Corresponding author. E-mail: blythe@pss.msstate. edu.
Department of Agriculture (USDA) hardiness zones 7 to 9, 'Dwarf Burford' holly is useful as a hedge, border, and screening plant, and is suitable for growing as a specimen plant, planting in containers, and training as an espalier (Gilman, 1999). Although plants are self-fertile and produce some bright red berries in the fall and winter (Gilman, 1999), they are grown primarily for their form and foliage (Berry, 1994).

'Dwarf Burford' holly can be propagated by stem cuttings at multiple times during the year. Newly matured or semimature wood is preferred as cutting material (Berry, 1994). Auxin treatment has traditionally been recommended and used in commercial propagation for rooting cuttings. Knight et al. (1993) rooted stem cuttings of 'Dwarf Burford' holly prepared from dormant shoots in early March and treated with a 5-s basal quick-dip in a solution of the potassium (K) salt of indole-3-butyric acid (K-IBA) at $3000 \mathrm{ppm}$. Dirr and Heuser (1987) reported that plants could be successfully propagated using cuttings made as late as April in Georgia, and noted that the use of auxin (such as IBA at 1000-3000 ppm) was warranted. Berry (1994) reported that Flowerwood Nursery (Loxley, AL) treated cuttings with a solution containing $6250 \mathrm{ppm} \mathrm{IBA} \mathrm{+}$ $750 \mathrm{ppm}$ 1-naphthaleneacetic acid (NAA).

In a study examining the application of auxin to cuttings via the rooting substrate, Blythe et al. (2004) noted that cuttings of dwarf yaupon holly (Ilex vomitoria 'Nana') and 'Nigra' inkberry (Ilex glabra) prepared in January could be successfully rooted without use of an auxin treatment, although some K-IBA treatments could produce larger root systems on cuttings compared with nontreated cuttings. In a study by Blythe and Sibley (2007) examining the use of a thickening agent for preparation of auxin solutions, cuttings of dwarf yaupon holly taken in early March rooted well without use of an auxin treatment, although the number of roots and total root length showed a tendency to increase with increasing auxin concentration from 0 ppm IBA +0 ppm NAA to 1000 ppm IBA + 500 ppm NAA.

The elimination of unneeded steps is critical to improving nursery production processes (Blythe and Sibley, 2001). Baldwin and Stanley (1981), in discussing work flow and costing in cutting propagation, noted the treatment of cuttings with auxin to be one of several operations that merit attention. The objective of the present study was to determine whether winter stem cuttings of 'Dwarf Burford' holly could be propagated without the use of a conventional basal quick-dip in auxin, thus eliminating one step in

\begin{tabular}{llll}
\hline $\begin{array}{l}\text { Units } \\
\text { To convert U.S. to SI, } \\
\text { multiply by }\end{array}$ & U.S. unit & SI unit & $\begin{array}{l}\text { To convert SI to U.S., } \\
\text { multiply by }\end{array}$ \\
\hline 0.3048 & ft & $\mathrm{m}$ & 3.2808 \\
2.54 & inch(es) & $\mathrm{cm}$ & 0.3937 \\
25.4 & inch $(\mathrm{es})$ & $\mathrm{mm}$ & 0.0394 \\
16.3871 & inch & $\mathrm{cm}^{3}$ & 0.0610 \\
1 & ppm & $\mathrm{mg}^{3} \cdot \mathrm{L}^{-1}$ & 1 \\
$\left({ }^{\circ} \mathrm{F}-32\right) \div 1.8$ & ${ }^{\circ} \mathrm{F}$ & ${ }^{\circ} \mathrm{C}$ & $\left(1.8 \times{ }^{\circ} \mathrm{C}\right)+32$
\end{tabular}


the cutting propagation process for this cultivar.

\section{Materials and methods}

Cutting propagation material of 'Dwarf Burford' holly was collected from mature landscape plants growing on the campus of Auburn University, Auburn, AL (lat. $32^{\circ} 36^{\prime} \mathrm{N}$, long. $85^{\circ} 29^{\prime} \mathrm{W}$, USDA hardiness zone 8a) for three experiments. A single plant provided material for Expts. 1 and 2, while an adjacent plant (the same age and growing conditions as the first plant) provided material for Expt. 3. Terminal, semihardwood, 3 -inch-long stem cuttings were prepared using the previous season's growth (stems being firm but green), with the lowest leaf removed from the base of each cutting.

Auxin solutions were prepared by diluting IBA + NAA (Dip 'N Grow; Dip 'N Grow, Inc., Clackamas, OR) with deionized water. In all experiments, cuttings received no auxin treatment or a 1-s basal quick-dip to a depth of 0.5 inch in a solution of $2500 \mathrm{ppm} \mathrm{IBA}+1250 \mathrm{ppm}$ NAA. In Expt. 1, cuttings in a third treatment received a 1 -s basal quick-dip to a depth of 0.5 inch in a solution of 5000 ppm IBA + 2500 ppm NAA; this treatment was not included in Expt. 2 or Expt. 3 based on preliminary results in Expt. 1. Cuttings were inserted to a depth of 0.5 inch into individual pots containing a commercial blend of peat, perlite, vermiculite, and pine bark (Fafard 3B; Conrad Fafard, Agawam, MA) as the rooting substrate. Containers used were polystyrene sheets of square pots [1] inch $^{3}$ soil volume per pot (X-3SQSP; Landmark Plastics, Akron, $\mathrm{OH})$ ] placed into plastic trays (L1020NCR; Landmark Plastics).

Expt. 1 was initiated on 29 Dec. 2001, Expt. 2 was initiated on 17 Feb. 2002, and Expt. 3 was initiated on 23 Feb. 2002. Cuttings were placed inside a 4 - $\mathrm{ft}$-wide by 8 -ft-long by 3 -ft-high polyethylene-covered enclosure on top of a 3 -inch layer of moistened pine bark (to maintain high humidity) within a double-layer, polyethylene-covered greenhouse at the Paterson Greenhouse Complex at Auburn University. Overhead mist was provided within the rooting enclosure by three $2.8-\mathrm{mm}$ orifice nozzles (Pin-Perfect; Dramm Corp., Manitowoc, WI) spaced $3 \mathrm{ft}$ apart and raised $\mathrm{l} \mathrm{ft}$ above the cuttings. Overhead mist was supplied once daily for $10 \mathrm{~s}$ at noon to maintain a relative humidity of $95 \%$ to $100 \%$. Maximum photosynthetically active radiation in the enclosure at the level of the cuttings was $600 \mu \mathrm{mol} \cdot \mathrm{m}^{-2} \cdot \mathrm{s}^{-1}$. Daily maximum and minimum temperatures were $81 \pm 10^{\circ} \mathrm{F}$ and $64 \pm 5^{\circ} \mathrm{F}$, respectively. Temperature and humidity were monitored with a data logger (HOBO Pro RH/Temp; Onset Computer, Bourne, MA) placed with the cuttings.

A completely randomized design was used in all experiments with 30 cuttings (replications) per treatment in each experiment. The number of rooted cuttings, number of primary roots emerging from the stem of each rooted cutting, total length of primary roots on each rooted cutting, number of rooted cuttings with new shoots, and total shoot length on each rooted cutting were determined after a rooting period of $145 \mathrm{~d}$ in each experiment. A cutting was considered to be rooted if it had at least one root $>0.5$ inch in length. In Expt. 1, significance of an increase or decrease in response variable values with increasing auxin concentration (a positive or negative slope coefficient in a regression model) was evaluated with Wald chi-square statistics [using the LOGISTIC procedure of SAS (version 9.1; SAS Institute, Cary, NC) for percentage rooted and percentage of rooted cuttings with new shoots and the GENMOD procedure (with the negative binomial distribution and a $\log$ link function) of SAS for number of roots] and t statistics (using the GLM procedure of SAS for total root length and total shoot length). In Expt. 2 and Expt. 3, between-treatment differences in number of rooted cuttings and number of rooted cuttings with new shoots were evaluated with Fisher's exact test using the FISHER option of the MULTTEST procedure of SAS. Betweentreatment differences for all other variables in Expt. 2 and Expt. 3 were evaluated with permutation tests using the TEST and PERMUTATION options of the MULTTEST procedure of SAS.

\section{Results and discussion}

The rooting percentage tended to decrease with increasing auxin concentration in Expt. 1, while the rooting percentage of nontreated cuttings was similar to that of cuttings treated with $2500 \mathrm{ppm} \mathrm{IBA}+1250$ ppm NAA in Expt. 2 and Expt. 3 (Table 1). The number of roots per rooted cutting was similar among treatments in all three experiments. The total root length per rooted cutting was similar among treatments in Expt. 1 and Expt. 2, but was greater on cuttings treated with 2500 ppm IBA + 1250 ppm NAA compared with nontreated cuttings in Expt. 3. In general, rooting percentages, root number, and total root length appeared to be greater with cuttings taken in the latter half of February compared with cuttings taken in late December; however, this would need to be confirmed by results of a multiyear test with appropriate statistical analysis.

Unlike rooting responses, which were relatively consistent from one experiment to another, initial shoot growth responses were variable among the three experiments. The percentage of rooted cuttings with new shoots and total shoot length tended to decrease with increasing auxin concentration in Expt. 1 (Table 1). In Expt. 2, there was no significant difference for these two variables between nontreated and auxin-treated cuttings, while cuttings treated with 2500 ppm IBA + 1250 ppm NAA exhibited a greater percentage of rooted cuttings with shoots and total shoot length than did nontreated cuttings in Expt. 3. Overall results indicate that nontreated cuttings and cuttings treated with $2500 \mathrm{ppm} \mathrm{IBA} \mathrm{+}$ $1250 \mathrm{ppm}$ NAA are capable of producing acceptable shoot growth after rooting; however, cuttings treated with 5000 ppm IBA + 2500 ppm NAA may exhibit reduced initial shoot growth due to the shoot-suppressive action of auxin at this higher concentration. Inhibition of shoot growth with increasing concentration of applied auxin has been demonstrated in previous studies with stem cuttings of woody plants (Blythe et al., 2003; Sun and Bassuk, 1991).

While it has previously been reported that 'Dwarf Burford' holly may be successfully propagated by stem cuttings taken late into the winter using an auxin treatment (Dirr and Heuser, 1987), results from the present study indicated that winter cuttings will root well without 
Table 1. Rooting and initial shoot development responses of terminal, semihardwood stem cuttings of 'Dwarf Burford' holly treated with and without auxins [indole-3-butyric acid (IBA) + 1-naphthaleneacetic acid (NAA)] in three experiments initiated during winter. ${ }^{\mathrm{z}}$

\begin{tabular}{|c|c|c|c|c|c|}
\hline $\begin{array}{l}\mathrm{IBA}+\mathrm{NAA} \\
\text { rate }(\mathrm{ppm})^{\mathrm{y}}\end{array}$ & $\begin{array}{c}\text { Rooted } \\
(\%)\end{array}$ & $\begin{array}{c}\text { Roots } \\
\text { (no.) }\end{array}$ & $\begin{array}{c}\text { Total root } \\
\text { length }(\mathrm{mm})^{\mathrm{x}}\end{array}$ & $\begin{array}{c}\text { Rooted cuttings } \\
\text { with new } \\
\text { shoots (\%) }\end{array}$ & $\begin{array}{c}\text { Total length } \\
\text { of new } \\
\text { shoots }(\mathrm{mm})\end{array}$ \\
\hline \multicolumn{6}{|c|}{ Expt. 1} \\
\hline Nontreated & 67 & 6.2 & 266 & 75 & 16.0 \\
\hline $2500+1250$ & 63 & 6.6 & 281 & 53 & 9.6 \\
\hline $5000+2500$ & 27 & 7.4 & 277 & 38 & 3.9 \\
\hline Significance ${ }^{w}$ & 0.003 & 0.421 & 0.883 & 0.055 & 0.041 \\
\hline \multicolumn{6}{|c|}{ Expt. 2} \\
\hline Nontreated & 93 & 7.9 & 444 & 14 & 6.1 \\
\hline $2500+1250$ & 93 & 8.6 & 513 & 18 & 3.6 \\
\hline Significance $^{v}$ & 1.000 & 0.510 & 0.233 & 1.000 & 0.802 \\
\hline \multicolumn{6}{|c|}{ Expt. 3} \\
\hline Nontreated & 90 & 9.1 & 419 & 19 & 7.3 \\
\hline $2500+1250$ & 83 & 10.4 & 624 & 56 & 20.0 \\
\hline Significance $^{\mathrm{v}}$ & 0.707 & 0.236 & 0.001 & 0.009 & 0.066 \\
\hline
\end{tabular}

${ }^{2}$ Expt. 1: 29 Dec. 2001; Expt. 2: 17 Feb. 2002; Expt. 3: 23 Feb. 2002 ( $\mathrm{n}=30$ in all experiments). Cuttings were rooted in a commercial blend of peat, perlite, vermiculite, and pine bark in a warm, high-humidity rooting environment inside a greenhouse with a rooting period of $145 \mathrm{~d}$ for each experiment.

${ }^{y} 1 \mathrm{ppm}=1 \mathrm{mg} \cdot \mathrm{L}^{-1}$

${ }^{\mathrm{x}} \mathrm{l} \mathrm{mm}=0.0394$ inch.

" $P$ values for slope parameters for percentage rooted, number of roots, and percentage of rooted cuttings with new shoots were obtained using Wald chi-square statistics.

${ }^{\vee} P$ values for differences between means in Expt. 2 and Expt. 3 were obtained using Fisher's exact test (for percentage rooted and percentage of rooted cuttings with new shoots) and permutation tests (for all other variables).

use of an auxin treatment. While the use of an auxin may sometimes produce larger root systems compared with nontreated cuttings, the use of auxin at a higher concentration can have a negative effect on rooting percentage. Because treatment with auxin was not required for successful rooting, one step in the propagation process could be eliminated for this holly, thus reducing labor and chemical costs.

\section{Literature cited}

Baldwin, I. and J. Stanley. 1981. Work flow and costing in propagation. Combined Proc. Intl. Plant Prop. Soc. 31:366-376.

Berry, J. 1994. Propagation and production of Ilex species in the southeastern United States. Combined Proc. Intl. Plant Prop. Soc. 44:425-429.

Blythe, E.K. and J.L. Sibley. 2007. Sodium cellulose glycolate as a thickening agent for liquid auxin formulations can enhance rooting of stem cuttings. J. Environ. Hort. 25:126-130.

Blythe, E.K., J.L. Sibley, K.M. Tilt, and J.M. Ruter. 2003. Cutting propagation with auxin applied via a stabilized organic rooting substrate. Combined Proc. Intl. Plant Prop. Soc. 53:275-283.

Blythe, E.K., J.L. Sibley, K.M. Tilt, and J.M. Ruter. 2004. Auxin application to stem cuttings of selected woody landscape plants by incorporation into a stabilized organic rooting substrate. J. Environ. Hort. 22:63-70.

Blythe, G. and J.L. Sibley. 2001. The effective propagator: Keeping a focus on key issues in propagation management. Combined Proc. Intl. Plant Prop. Soc. 51:590-594.

Dirr, M.A. 1998. Manual of woody landscape plants: Their identification, ornamental characteristics, culture, propagation and uses. Stipes Publishing, Champaign, IL.

Dirr, M.A. and C.W. Heuser, Jr. 1987. The reference manual of woody plant propagation: From seed to tissue culture. Varsity Press, Athens, GA

Galle, F.C. 1997. Hollies: The genus Ilex. Timber Press, Portland, OR.

Gilman, E.F. 1999. Ilex cornuta 'Burfordii Nana'. Univ. Florida Coop. Ext. Serv. Fact Sheet FPS-263.

Knight, P.R., D.J. Eakes, C.H. Gilliam, and K.M. Tilt. 1993. Propagation container size and duration to transplant on growth of two Ilex species. J. Environ. Hort. 11:160-162.

Sun, W.Q. and N.L. Bassuk. 1991. Effects of banding and IBA on rooting and budbreak in cuttings of apple rootstock 'MM.106' and Franklinia. J. Environ. Hort. 9:40-43. 